\title{
Lights, Catalogs, Archives!: A Selected Annotated List of Web Resources for Film and Television Studies
}

David D. Oberhelman, Professor, Humanities-Social Sciences Division, Oklahoma State University Library, Stillwater, Oklahoma, USA

Purpose - The purpose of this paper is to provide a selected list of free and subscription Web resources for film and television (screen) studies.

Design/methodology/approach - Reference sources on film and other media studies were located, evaluated, and selected. The list is divided into four broad research categories: Research Databases and Film Catalogs (Subscription Products), Film and Television Catalogs/Databases (Gratis), Historical Film Streaming Sites, and Film Studies Portal Sites.

Findings - There are a wide variety of resources available online that users can freely access as well as robust subscription products currently available to libraries to support research in film and television studies. Students and scholars can use both free and fee-based sites for film catalogs, film studies journal indexes, streaming video content, and other information and analysis on visual media.

Originality/value - There has not been a bibliographic list of online film studies resources undertaken since 2005, and many new Web resources as well as databases have emerged in the field. The annotated list of resources in this study seeks to supplement and update what has been previously discussed in the LIS literature on Web-based reference sources available for libraries supporting film and television studies.

\section{Introduction}

Twenty-first century scholars of film and cinema studies — or "screen studies" as many new call the field to encompass not only film, but also television and emerging digital media formatshave been greatly aided by the emergence of many factual and critical sources, catalogs, and other databases on the World Wide Web, replacing the often cumbersome and easily superseded print sources that formed the mainstay of library reference collections. The number of free sites has grown exponentially in recent years, and subscription fee-based sites continue to offer solid, scholarly information on film as well as other content. There have been some annotated bibliographies for libraries in the last decade (Albitz 2005), but the film and entertainment portal sites have changed greatly over the years.

What follows is a very limited, selected list of Web resources, both gratis sites and subscription products, along with brief annotations to aid librarians seeking an overview of online tools for the study of film, television, as well as new forms of digital media. This list is not meant to be a comprehensive bibliographic survey, but an introduction to what is available now for the enthusiast as well as the serious researcher interested in the history of motion pictures in all their 
formats. The focus of this list is on feature films and some television programming, but it also covers some resources for documentaries and educational films as well. It is divided into four sections: subscription research databases and film catalogs, gratis film and television catalogs, streaming film sites, mainly for historical film (commercial video uploading sites such as YouTube and Vimeo, as well as individual subscription streaming services such as Netflix, Hulu, and Amazon Prime Video are beyond the scope of this paper), and finally film studies portal sites, both general and academic, which include commercial movie sites, online film journals, and sites for film facts, filmographies, reviews, criticism, entertainment, and scholarly analysis.

\section{Research Databases and Film Catalogs (Subscription Products)}

Film Literature Index (FLI) Online (webapp1.dlib.indiana.edu/fli/index.jsp) and Film \& Television Literature Index with Full Text (FTLI) (www.ebscohost.com/academic/filmtelevision-literature-index-with-full-text) comprise both a free and fee-based version of one of the standard reference sources for film research. The print periodical version of this index, the first devoted exclusively to film for researchers, students, and other readers, appeared in 1973. Published annually from 1973 to 2004 by the Film and Television Document Center at the State University of New York (SUNY), this reference tool indexed over 150 film and television journals, trade publications, and magazines from over thirty countries (with selective indexing of many more periodicals). The contents include academic analysis of film, reviews, articles on the motion picture industry, and film journalism, and in later years television is included as well. There are both free and subscription versions of the original print index available now that the print publication has ceased. In 2002 the Digital Library Program at Indiana University in collaboration with the SUNY center received a National Endowment for the Humanities grant to create a digital version of the index, FLI Online, with searchable citations form 1976 to 2001. This free online version allows users to browse by subject headings, personal names, production titles, or corporation names, and has a very basic search function for keyword, production title, or person. The full citations contain extensive subject and name headings, but are citation only. Academic libraries may also want to get the EBSCOhost Film \& Television Literature with Full Text (FTLIFT) which spans 1990 to the present and has 120 full-text journals, extended coverage of Variety, and over 36,000 images. This database used the EBSCOhost platform and has both html full text and PDF versions, and is a valuable product for libraries supporting large film collections.

FIAF International Index to Film Periodicals (fiaf.chadwyck.com) from the International Federation of Film Archives began in 1973 as an index of over 300 academic and popular film journals, and is available electronically on ProQuest's Chadwyck-Healy platform along with FIAF International Index to Film Periodicals Plus with full-text for important journals such as Sight and Sound. The database is also enhanced with archival materials related to film that will benefit researchers. It has credit and holdings information for over 40,000 silent films and shorts, most produced prior to 1929, and also includes the International Directory of Film/TV 
Documentation Collections. There is some overlap with FTLI, but FIAF has some unique titles, and the added archival catalogs make this product very useful to both scholars and students.

Film Index International (fii.chadwyck.co.uk), also from ProQuest's Chadwyck Healy, is an online catalog indexing over 125,000 international films from the silent era to the present and over 800,000 personalities connected to the entertainment industry. Based on the British Film Institute's Summary of Film and Television (SIFT) database, the records for films over detailed cast and credit information, lists of awards, and references to reviews and detailed analyses of the film in film journals. A durable url is available to help users quickly navigate to specific film information. The person search record gives biographical overviews of actors, directors, writers, producers, and other others, and offers summaries of their careers in the film industry. It is comparable to the standard print Magill's Cinema Annual reference guide, and some of the free catalogs available on the Web (some of which are discussed in the section below), but Film Index International has the broadest coverage of world cinema and is in-depth enough to satisfy film researchers seeking an authoritative source.

\section{Film and Television Catalogs/Databases (Gratis)}

American Film Institute (AFI) Catalog of Feature Films (www.afi.com/members/catalog/) from the national arts organization in the United States dedicated to preserving the country's film heritage and training filmmakers, maintains its own free database of nearly 60,000 feature-length films and 17,000 shorts produced from 1893 to 2011, and the AFI Awards Outstanding Movies of the Year from 2000-2010. The records in the catalog have full cast and crew lists, and give plot summaries of the films. Additional information is available to give expanded notes, often with critical analysis and historical background for the films, as well as information about the score and other aspects of the film. The basic search mode allows users to search the catalog records by film title, personal name (actor or crew member), or company name, or to search the AFI's subject headings or keywords, and the advanced search has additional full-text search fields. The AFI Catalog offers expert criticism on the films that will help researchers and students interested in the making of motion pictures, and it is an essential reference tool American cinema history.

British Film Institute (BFI) Film \& TV Database (ftvdb.bfi.org.uk/searches.php) is the BFI's database of film and television programs as well as actors, producers, and other people connected with the entertainment industry; it consists of over 810,000 entries. The database is searchable by title, personal name, organization, or event. The records for films and television shows provide cast and crew information, and basic production information. Unlike the AFI catalog, there are no critical notes in the fairly brief entries, but the coverage is quite extensive and international in its scope. This source is very useful for quick lookup of names and production facts. Note: the database homepage indicates that the catalog is currently closed to new information until further notice. 
Internet Movie Database (IMDb) (imdb.com) and IMDb: Advanced Title Search (imdb.com/search/title) is, among the popular entertainment reference sources on the Web, one of the most popular and frequently consulted, and its extensive cast and crew credit listings as well as other production information make it a valuable tool for both the casual viewer and the more advanced enthusiast and researcher to consult. It includes not only feature films and television programming, but also documentaries, news programs, video games, and other forms of media, making it a vast catalog of all video formats. The listings for people and titles are very extensive, and the IMDb Pro subscription service is popular with those who work in the industry and desire additional layers of information (including artistic representation and production company contact information). The IMDb Advanced Search interface allows users to search by genre, IMDb "groups" (including award-winners), companies, and video format as well as retailer information for home video. Although there are occasional errors in listings and the site allows user-submitted information, it is a database that many consult first when seeking answers related to all things in the world of media.

\section{Historical Film Streaming Sites}

Internet Archive - Moving Image Archive (www.archive.or/detail/movies) contains streaming and downloadable feature films, film shorts, clips, and videos. This library contains thousands of digital movies, out-of-copyright films, and other videos uploaded by Archive users which range from classic full-length films in many genres, to daily alternative news broadcasts, to documentaries, to cartoons and concerts. Many of these videos are available for free download. It includes the Prelinger Archive of ephemeral films (advertising, educational, business, industry, and amateur films).

Edison Motion Pictures (memory.loc.gov/ammem/edhtml/edmvhm.html) from the Library of Congress American Memory collection, includes 341 films by Thomas Edison and his production company from 1891 to 1918 . This site is of great interest to silent film researchers seeking films by one of the pioneers of early American cinema.

Origins of American Animation (memory.loc.gov/ammem/oahtml/oahome.html), another American Memory site, contains twenty-one early American animated film shorts made from 1900 to 1921 . These animated motion pictures document the history of the genre and the social conditions surrounding film in the early 1900s.

Alexander Street Press Video Collections (alexanderstreet.com/products/video-collections) is a growing suite of subscription-based streaming video products from Alexander Street Press. Subcollections include Asian Films Online with over 600 documentaries, shorts, and other clips related to Asia, historical newsreel packages including the March of Time shorts, and theatrical, musical, and educational videos in disciplines ranging from anthropology to psychology and even engineering. 


\section{Film Studies Portal Sites}

CineSpot.com (www.cinespot.com) offers reviews, box office charts, sections on genres, and links to general information on the film industry.

Film Site (www.filmsite.org/) is a general portal site with links and information on classic cinema for film "buffs" as well as students and other researchers.

Film and Television - EServer (filmtv.eserver.org/) offers links to film analysis and other resources of media studies criticism from the "English Server" humanities portal.

Images: A Journal of Film and Popular Culture (www.imagesjournal.com/) is an online quarterly journal devoted to the analysis of movies, television, videos, and other visual arts. It has both critical articles and reviews, and "in focus" sections on themes such as the films of Hitchcock or the Western genre.

The Movie Review Query Engine (www.mrqe.com) is the Internet's largest database of online film reviews for over 100,000 titles worldwide. The site provides a searchable index of all published and available reviews, news, interviews, and other materials associated with specific films.

Moving Image Source (www.movingimagesource.us) from the Museum of the Moving Image is a gateway to the best online resources related to film, television, and digital media.

ScreenSite (screensite.org) is a film studies portal designed especially for studying visual style in film.

Senses of Cinema (sensesofcinema.com) is an online journal based in Australia that is devoted to the academic study of film, theory, ideology, and other critical issues related to cinema.

The Silent Era (www.silentera.com) is a large collection of news items and other information related to silent films. It contains filmographies, lists of lost films, and articles on the early cinema.

\section{References}

Albitz, R. S. (2009). From celluloid to digital: electronic resources for film studies. Journal of library administration, vol. 43, no.3/4, pp. 55-63.

Oberhelman David, (2014),"Lights, catalogues, archives!: a selected annotated list of web resources for film and television studies", Reference Reviews, Vol. 28 Iss 1 pp. 2 - 5 Permanent link to this document: http://dx.doi.org/10.1108/RR-06-2013-0145. 